\title{
The Extraterritorial Application of European Contract Law
}

\author{
María Asunción CEBRIÁN SALVAT*
}

\begin{abstract}
Regarding international contracts the European Union has not only launched a private international law unification but also a substantive harmonization in certain sectors, such as consumers or commercial agency. These substantive law rules and private international law rules must be coordinated. When they are not, there is a high risk of applying European contract law extraterritorially. To prevent this risk, this paper proposes the application of the "multilateral theory" to the interpretation of European contract law's scope of application.
\end{abstract}

Keywords: European Union law, international contracts, scope of application, extraterritoriality, Rome I Regulation.

\section{EUROPEAN CONTRACT LAW: CONCEPT AND RECENT DEVELOPMENTS}

European law started as an institutional law for the functioning of the European bodies but this perspective cannot be borne out by reality anymore. European substantive law has become very relevant and hitherto has harmonized many sectors of Member States' national laws. Firstly, this harmonization was based in the consecution of an internal market, but nowadays it is also aimed at the creation of a common area of freedom, security and justice for all European citizens. ${ }^{1}$

With reference to private law, the European Union has made harmonization efforts in two directions: firstly, towards the unification of conflict-of-laws rules and secondly, towards the unification of some aspects of substantive private law. The latter was justified by the European lawmaker on the ground that obstacles to freedom of circulation would exist albeit a whole private international law harmonization. This is especially remarkable in some sectors like consumer law, in which national differences generate unbearable costs to citizens that seek to establish cross-border relations. ${ }^{2}$

Assistant Researcher of Private International Law, University of Murcia, masuncion.cebrian@um.es. This paper is a result of the doctoral contract granted to the author by Fundación Séneca, Agencia de Ciencia y Teconología de la Región de Murcia (Consejería de Industria, Empresa e Innovación de la Comunidad Autonóma de la Región de Murcia).

E. Poillot, Droit européen de la consommation et uniformisation du droit des contrats (LGDJ, Paris, 2006), at I53. On this harmonization in civil matters see also H. Aguilar Grieder, 'La cooperación judicial internacional en materia civil en el Tratado de Lisboa', 2 CDT (2010) 308-338; J.J. Álvarez Rubio, 'El tratado de Lisboa y la plena comunitarización del espacio de libertad, seguridad y justicia', I5 REEI (2008) I-33, online version available at: http://www.reei.org/index.php/revista/numis/articulos/tratado-lisboa-plena-comunitarizacion-espacio-libertad-seguridadjusticia (last visit 2 October 2015).

2 Vid. Explanatory Memorandum of the Proposal for a Regulation of the European Parliament and of the Council on a Common European Sales Law, COM/20II/0635 final, text available at: http://eur-lex.europa.eu/legalcontent/ES/TXT/HTML/?uri=CELEX:520IIPC0635\&from=en (last visit 2 October 2015). 
One of the sectors of private law where substantive harmonization has been achieved at a significant degree is contract law. This is easily explained if it is taken into account that contracts are the 'par excellence' instruments of international economic exchange. ${ }^{3}$

In contrast, the law of contract is usually one of the 'emblems' of national legal traditions. This originated some resistance to its harmonization, especially from countries with a longstanding legal tradition such as France. ${ }^{4}$ However, some academics underline that these differences have been exaggerated and that in fact Member States have a common "contractual culture".s

\section{(I) The Concept of European Contract Law}

According to its current state of development, European contract law can be defined as the set of rules of European origin that apply to some contractual relations between individuals. ${ }^{6}$ Hitherto, it is formed by a complex accumulation of sector specific rules applicable to certain contractors and issues.

In relation to this concept, the meaning of "contractual" shall be clarified. The aforementioned term has been defined by the European Court of Justice (hereinafter, 'ECJ') in the field of private international law, particularly in relation to the first version of Brussels I Regulation, currently replaced by Brussels I Regulation Recast.7 In one of the cases decided on this matter by the ECJ, Česká sporitelna, contractual obligations were defined as obligations freely assumed by one party towards another. ${ }^{8}$ This definition seems to include donations and unilateral promises.?

Whether this definition of private international law is extended to substantive European law must be decided. The most logical answer would be the affirmative one, given that

\footnotetext{
P. Ancel, 'Le droit des contrats: Les frontières du droit privé européen en matière contractuelle à l'épreuve de la proposition de règlement sur le Droit commun européen de la vente', in E. Poillot et al., Les frontières du Droit privé européen (Larcier, Bruxelles, 2012) 257, at 259.

4 See for example Y. Lequette, 'Le code européen est de retour', 3 RDC (2011) I028-I044, at IO29; B. Fauvarque-Cosson, 'Faut-il un code civil européen ?' in B. Fauvarque-Cosson and D. Mazeaud (dirs), Pensée juridique française et barmonisation européenne $d u$ droit (SLC, Paris, 2003), 99-126; Commission Communication of 12 February 2003, 'A more coherent European contract law, an action plan', COM (2003) 68 final, paragraph 7: "A majority was, at least at this stage, against option IV, which aimed at a new instrument on European contract law".

C. Prieto, 'Une culture contractuelle commune en Europe', in C. Prieto (dir), Regards croissés sur les Principes du droit européen du contrat et sur le Droit français (Presses Universitaires d'Aix-Marseille, Aix-Marseille, 2003), 17-42; C. Witz, 'La longe gestation du droit européen des contrats, rappel des quelques initiatives oubliées', 3 RTD civ. (2003), 447-458.

6 E. Poillot, 'La notion de droit privé européen', in in E. Poillot et al., Les frontières du Droit privé européen (Larcier, Bruxelles, 2012) 9-30, at I8.

7 Council Regulation 44/200I ('Brussels I Regulation'), OJ 200I L oI2/, substituted by EP and Council Regulation I215/20I2 ('Brussels I Regulation Recast') OJ 20I2 L 35I/.

8 Judgment in Česká spořitelna, C-419/II, EU:C:2013:I65, paragraph 46: "obligation freely assumed by one party towards another".

9 On this decision, L. Lalot, 'Précisions sur les notions de « consommateur » et de «matière contractuelle » au sens du règlement Bruxelles I', 82 Revue Lamy droit des affaires (2013) 40-45; A. Passarella, 'Regolamento sulla competenza giurisdizionale e nozione di consumatore', 5/2013 Giurisprudenza italiana (2013) IOII-IOI2.
} 
European private international law takes its own characterization categories from European autonomous concepts. However, attention shall also be paid to the definitions that are contained in some European contract law instruments, since these definitions will determine if the relevant instrument will be applied to a certain legal relation.

\section{(2) The Main Instruments of European Contract Law}

This paper will only address the study of "traditional" sources of European Union's unilateral secondary law, precisely directives and regulations, given that they are the main source of European contract law. ${ }^{\text {Io }}$

The most relevant rules issued hitherto are related to consumer rights; ${ }^{\text {:I }}$ employment contracts; $;{ }^{12}$ insurance; ${ }^{13}$ financial transactions; $; 4$ late payment: ${ }^{15}$ commercial agents; ${ }^{16}$ product liability; ${ }^{17}$ electronic commerce ${ }^{18}$; and package travel. ${ }^{19}$ Some other instruments are in a drafting phase like the rules on cloud computing. The Common European Sales Law Regulation proposal (hereinafter, CESL), was withdrawn some months ago. ${ }^{20}$

As it can be extracted from the list above, the sector specific harmonization of contract law has been mainly undertaken by the means of directives and not by regulations. This choice of the European legislature is not neutral. It reflects its awareness that contract law is, as it was stated herein, an issue strongly linked to national traditions. Therefore, room is left for Member States' lawmakers to adapt the legislation to their own legal system in the transposition phase.

However, this position is evolving. In the early years of harmonization, most contract law directives were "minimal" harmonization directives (i.e. Directive on commercial agency). After 2002, the new approach of the Commission has privileged "total" harmonization

ro Sources of unilateral secondary law are divided in "typical" or "traditional" acts, which are those acts listed in art. 288 of the Treaty on the Functioning of the European Union ("TFEU"): regulations, directives, decisions, opinions and recommendations, and "atypical" acts, which are those acts that are not listed in art. 288 of the TFEU: communications, recommendations, and white and green papers. In this respect, see: http://eur-lex.europa.eu/legalcontent/EN/TXT/?uri=uriserv:li4534.

II The most relevant are the European Parliament and Council Directive 20II/83/EU on consumer rights, OJ 20II L 304/64; EP and Council Directive 1999/44/EC on consumer guarantees, OJ 1999 L 171/I2; Council Directive 93/I3/EEC on unfair terms in consumer contracts, OJ $1993 \mathrm{~L} 95 / 29$.

12 Council Directive 9I/533/EEC on employer's obligation to inform employees, OJ 1991 L 288/32; Council Directive $2000 / 78 /$ EC on equal treatment in employment, OJ $2000 \mathrm{~L} 303 / 16 .^{2}$

${ }_{13}$ European Parliament and Council Directive 2002/83/EC on life assurance, OJ $2002 \mathrm{~L}$ 345/I.

${ }_{14}$ European Parliament and Council Directive 2004/39/EC on markets in financial instruments, OJ 2004 L I45/I.

is European Parliament and Council Directive 20II/7/EU on late payment, OJ 20II, L 48/I.

16 Directive $86 / 653 /$ EEC on commercial agents, OJ 1986 L 382/17.

17 Council Directive 85/374/EEC on liability for defective products, OJ $1985 \mathrm{~L} 210 / 29$.

i8 European Parliament and Council Directive 2000/3I/EC on electronic commerce, OJ 2000, L I78/I.

19 Council Directive 90/314/EEC on package travel, package holidays and package tours, OJ 1990 L 158/59.

${ }^{20}$ Proposal for a European Parliament and Council Regulation on a Common European Sales Law, COM/2011/0635 final $-2011 / 0284(C O D)$. 
directives. ${ }^{21}$ Moreover, one of the most recent drafts of the Commission, the aforementioned CESL, was a regulation. This suggests that the intention of the Commission is to overcome this first phase gradually and move to a stronger and more direct harmonization.

To conclude this section it is necessary to underline the role of the jurisprudence of the ECJ in the composition of European contract law. This role is much more than interpretative. ${ }^{22}$

\section{THE EXTRATERRITORIAL APPLICATION OF \\ EUROPEAN UNION CONTRACT LAW: THE PROBLEM}

All European contract law instruments have a "potential" territorial, material, personal and temporal scope of application that shall be identified in order to determine which rules apply to a certain contractual relation. When the case heard by a Member State's national court is a "domestic case", this is, a case that is only connected to the State where the courts are seised, the determination of the territorial scope of application would always be addressed from the perspective of the law of the forum, because the court will always apply its own rules. These rules will include the EU contract law instruments that have been transposed by that Member State.

However, when the case is connected with several states, either Member States or third countries, the national court shall also take into account private international law rules to determine which law shall be applied to resolve the dispute. In contract law, these private international law rules are also European. Under this scenario, the problem arises because the European Union contract law establishes its own territorial scope of application, and European Union private international law instruments may contradict that scope. The court seised will have to decide which provisions shall prevail, either those determining the territorial scope of the directive or those determining the law applicable to the contract.

(I) European Private International Law Applicable to Contractual Obligations

Rome I Regulation is the instrument that EU Member State Courts apply to determine the law applicable to contractual relations. ${ }^{23}$ Therefore, this Regulation will be used to determine if a certain contract shall be governed by the law of a Member State or by the law of a nonEU country.

\footnotetext{
${ }_{21} \quad$ M. Latina, 'L'impact de l'harmonisation européenne sur le droit commun des contrats', in M. Boumghar and V. Durand, Les nouvelles échelles du Droit Commun (Larcier, Bruxelles, 2013), 95-III, at 99.

22 As an example, see Judgment in VB Penzugyi, C-137/08, EU:C:2010:659.

23 European Parliament and Council Regulation on the law applicable to contractual obligations ('Rome I Regulation'), OJ $2008 \mathrm{~L} \mathrm{I77/6.}$
} 
When Rome I points to the law of a Member State, this law will include all potentially applicable European Union contract law rules, in the version that has been transposed by that Member State. Problems may arise either from a wrongful transposition of the directive by the Member State or from the absence of transposition at all, but these problems have been successfully solved by scholars and case law. ${ }^{24}$ From a traditional private international law perspective, it could be affirmed that in these cases Rome I Regulation "locates" the contractual relationship within the territory of the European Union.

In contrast, when Rome designates the law of a non-EU country, EU contract law seems to be excluded, given that EU law is not part of non-EU countries legislation. From a traditional private international law perspective, it could be affirmed that in these cases the Rome I Regulation "locates" the contractual relationship out of the borders of the European Union. For example, if a Spanish court hears a case arising from a sales contract between an Australian seller and a Spanish buyer, and the contract contains no choice-of-law clause, the court will designate Australian law as the law applicable to the contract, given that this is the law of the habitual residence of the seller (Article 4(I)(a) Rome I). In principle, this excludes the potential application of EU contract law.

However, EU contract law may contain provisions stating their territorial scope of application that apparently can contradict the designation of applicable law made by the Rome I Regulation. That is, there are occasions in which European contract law seems to be applicable to contractual relations even if the Rome I Regulation locates that relation out of the borders of the European Union ("extraterritorial application").

(2) The EU Contract Law Provisions on Territorial Scope of Application

The aim of European contract law is not to govern all contractual relations in the world, but only those who have a significant link with the European Union. This is an expression of the principle of "specialty" or "subsidiarity" of EU legislation, which means that the EU can only extend the application of its rules to situations allowed by primary law. ${ }^{25}$

To show the conformity with that primary law, secondary legislation uses to state its own scope of application. Some authors have stated that this scope of application may be different depending on the kind of instrument used by the European legislature, because they have a different legal basis: ${ }^{26}$ most of these instruments intend to harmonize national laws on the

\footnotetext{
24 S. Sánchez Lorenzo, 'La unificación del Derecho contractual europeo', en G. Palao Moreno et al., Derecho patrimonial europeo (Thomson Aranzadi, Navarra, 2003), 363-381, at 370.

${ }_{25}$ S. Leible, 'Kollisionsrechtlicher Verbraucherschutz im EVÜ und in EG-Richtlinien', in H. Schulte-Nölke / R. Schulze, Europäische Rechtsangleichung und nationale Privatrechte (Taschenbuch, Baden-Baden, 1999) 353-392; R. Michaels / H.G. Kamann, supra n. 24, at 37I.

26 M. Fallon, 'Les frontières spatiales du droit privé européen selon le droit de l'Union européenne' in E. Poillot et al., Les frontières du Droit privé européen (Larcier, Bruxelles, 2012) 65-I2I, at 68.
} 
legal basis of Article II4 of the Treaty on the Functioning of the European Union ("TFEU”), i.e. the aforementioned Consumer Rights Directive and others aim to overlay a distinctly European legal institution, without affecting national institutions, i.e. Regulation 207/2009 on the Community trade mark. ${ }^{27}$

Yet there is not a uniform trend. Some instruments contain a unilateral application rule, others a "true" multilateral conflict of laws rule, others do not refer to their scope of application. ${ }^{28}$

\section{(a) Instruments with a Scope of Application Rule}

The applicability rules contained in European contract law instruments can be classified in three different groups, according to the techniques used by the European lawmaker to give them a broader or narrower scope of application:

(i) Rules that use a single criterion of applicability, such as the first Timesharing Directive, which takes as its criterion the location of the property in the territory of a Member State (Article 9). ${ }^{29}$

(ii) Rules that use alternative applicability criteria, such as the Regulation on air passengers rights, which is applicable to the following two cases: contracts where the departure point is at an airport in the EU and contracts where the arrival point is an airport in the EU if the carrier is European and whether the foreign law that shall be applied to the case does not provide the passenger with an equivalent protection (Article 3).30 These alternatives show the will of the European legislature of a more extensive application.

(iii) Rules that use an indefinite applicability criterion, showing a kind of defensiveness of the European legislature to the law of third countries. This is the case of consumer directives such as the first Directive on unfair terms, according to which the consumer should not be deprived of the protection of mandatory rules established by the Directive if the contract presented "close links" with the territory of the EU (Article 6(2) Directive). ${ }^{\text {I }}$ This standard has been extensively interpreted by Member States' courts and the ECJ, who has acknowledged the existence of a close connection with the EU even in the case of a single link such as the residence of the consumer. ${ }^{32}$

In all these three cases, an important question is raised: shall the applicability in international cases be determined according to these provisions or shall it be left to general conflict rules in the Rome I Regulation?

27 Council Regulation 207/2009 on the Community trade mark, OJ 2009 L 78/I.

28 M. Fallon, 'Les frontières...', supra n. 26, at 84.

29 Council Directive 94/47/EC on “Timesharing”, OJ 1994, L 280/83.

30 Regulation 26I/2004 on air passenger rights, OJ $2004 \mathrm{~L}$ 46/I.

${ }_{31}$ Council Directive 93/13/EEC of 5 April 1993 on unfair terms in consumer contracts, OJ 1993, L 95/29.

32 Judgment in Commission of the European Communities $v$ Kingdom of Spain, C-70/03, EU:C:2004:505. 
(b) Instruments without a Scope of Application Rule

As it has been stated above, other European contract law instruments lack a scope of application rule. Most of these instruments were adopted before the 1990s. There are two major examples in the Directive on commercial agents and on the Directive on product liability.33

In these cases the absence of a particular application standard raises another relevant question: shall the applicability be left to the general conflict rules (Rome I Regulation) or shall the courts seek for an implicit rule of application?

\section{(3) The Risk of Extraterritoriality}

As it has been seen, the presence of a scope of application rule in a directive or regulation does not mean that the conflict of laws is automatically solved, particularly when connections with third states are involved.

These applicability rules shall be confronted with the Rome I Regulation, because sometimes the law designated by the latter will exclude the application of the law of a European country, which may contain the transposition of a directive whose applicability rule seems to make it applicable to the case. This can lead to many problems of legal certainty. Member State courts would not be able to determine if the law applicable to the case is the substantive law determined by the Rome I Regulation or the relevant European contract law instrument.

This problem will be framed more easily with the following example: a Spanish company contracted with a tour operator headquartered in Morocco a trip for all of its employees, which included the plane tickets, the accommodation and a circuit of tours for every day of the trip. The company achieved very good price conditions after negotiating with the tour operator, but instead had to pay the entire amount in advance. Three weeks before the trip, the Moroccan company informed the Spanish company that the flight departed from Paris instead of Madrid, and that the Spanish company had to bear with the costs of changing the tickets or of carrying its employees to Paris to take the flight. The Spanish company disagreed, and asked the tour operator for a refund. After its refusal, the Spanish company sued the tour operator before the Spanish courts.

On the assumption that Spanish courts asserted their jurisdiction under Article 22 quinquies (a) LOPJ (place of performance of the obligation located in Spain) they would apply the Rome I Regulation to determine the law applicable to the case. ${ }^{34}$ In the absence of a

33 Supra n. 16 and n. I7.

34 Organic Law 6/1985, I June, on Judicial Power [LOPJ] (BOE No. 157, 2 July 1985). 
choice of law agreement, and according to Article 4(I)(b) Rome I, the case would be governed by Moroccan law, the law of the habitual residence of the service provider.

However, the Spanish court may ask itself if it shall apply the Fourth Book of the General Consumer and User Protection Act that transposes the mentioned Directive on package travel. ${ }^{55}$ This law is applicable regardless of whether the purchaser is a natural or legal person and establishes a much more protective regime for the buyer than Moroccan law. The Spanish transposition act does not establish its territorial scope of application, but the European directive does so. It indicates that it shall apply to package travels "sold or offered for sale in the territory of the Community" (Article I). Supposing that in this case, the trip was sold on the territory of the European Union, the following question arises: shall the Member State court apply the European standard although the law applicable to the contract is Moroccan Law? That is, shall it apply the Directive "extraterritorially" ${ }^{36}$ How can the judge take a position?37

THE EXTRATERRITORIAL APPLICATION OF EUROPEAN UNION CONTRACT LAW: THE POSSIBLE SOLUTIONS

To solve the problem of the extraterritorial application of EU contract law the theories on the extraterritorial application of European private law in general will be applied to the specific field of contracts. These theories were designed for the generality of European private law, and none of them has been preferred by the ECJ.

This paper presumes that none of the existing theories may be valid for all the cases of extraterritorial application of European law and that, in contrast, some theories may work better for one field of European law than for others. This would be justified in the fact that not all European private law has the same nature (i.e. EU tort law is different from EU company law). This paper has selected a field of European private law (contract law) to illustrate the particularities of a branch of European law. The main particularity of this branch is that European contract law contains a conflict rule which is also European (Rome I Regulation) and it also contains rules related to the extraterritorial application of European Law. This does not happen in other fields like the aforementioned EU company law.

\footnotetext{
35 Royal Decree I/2007, 16 November, by which the restated text of the General Consumer and User Protection Act and other related provisions were approved ("Ley General para la Defensa de los Consumidores y Usuarios") (BOE No. 287, 30 November 2007). For the Directive, supra n. I9.

${ }^{36}$ For this concept of extraterritoriality and the differences with other concepts of the same term in European law: B. Audit, 'Extraterritorialité et commerce international: l'affaire du gazeoduct sibérien', Rev. crit. Dr. Int. Pr. (1983) 40I-434; J.G. Castel, 'The extraterritorial effect of antitrust laws', 179 RCADI (1983) 9-I44 [DOI : http://dx.doi.org/I0.II63/ej.9789024729487.009-I44]; N. Diacakis, Problèmes liés aux effets extraterritoriaux des normes communautaires (Bruylant, Brussels, 2000).

37 Example adapted from B. Mathieu, 'Directives européens et unilatéralisme' (Centre de recherche de Droit International Privé et du Commerce International, Paris Panthéon-Assas, 2015).
} 
This Rome I Regulation contains two specific rules on the extraterritorial application of European Union law. The first one is Article 3(4) of Rome I Regulation. According to it, imperative European Union law shall be applicable where all the elements relevant to the contract are located in the territory of a Member State, no matter the parties' choice of law and no matter the scope of application of such a European law instrument. This article is only applicable when the case is "artificially" connected to a third state in order to avoid the application of European Union Law, i.e. if in the aforementioned example the tour operator was German but included a choice of Moroccan law clause in the contract. In these cases, provisions of European Union law which cannot be derogated from by agreement, such as the abovementioned Directive on package travel, shall be applicable. As a consequence of the foregoing, this Article solves the problem when the connection with a third state is fictitious, but is not applicable when the connection with a third state is real and not only created by the choice of its law.

The second article that shall be considered is Article 23 Rome I. It states that the Regulation shall not prejudice the application of provisions of European Union law which, in relation to particular matters, lay down conflict rules relating to contractual obligations. As a consequence of the foregoing, the question that should be asked regarding extraterritoriality if the Rome I Regulations is taken into account in this specific field is whether these rules that determine the territorial scope of application of European contract law are "conflict rules relating to contractual obligations".

(I) Traditional Theories on the Scope of Application of European Union Private Law

To answer to the question whether the provisions determining the scope of application of a directive or a regulation are conflict rules two main theories can be referred:

\section{(a) Unilateralism}

The first theory is "unilateralism" or the theory of "unilateral conflict rules" ('règles d'applicabilité). According to it, directives and regulations have their own scope of application, which is determined via unilateral provisions (S. Franq)..$^{38}$ As a consequence of this theory, every time that a directive or a regulation determined its scope of application it would be creating a unilateral conflict rule. This means that these "specific" conflict rules would not be limited by traditional instruments of conflict-of-laws.

38 S. Franq, L'applicabilité du droit communautaire dérivé au regard des méthodes $d u$ Droit international privé (Bruylant, Brussels, 2005). Also R. Arenas García, 'El Derecho internacional privado (DIPr) y el Estado en la era de la globalización: la vuelta a los orígenes', in Cursos de Derecho internacional y relaciones internacionales de Vitoria-Gasteiz 2007 (Bilbao, Servicio Editorial de la Universidad del País Vasco, 2008) 19-94; S. Sánchez Lorenzo, supra n. 24. 
This theory is based on the statement that unilateralism is the "primitive" technique of private international law, that still needs to be used when the multilateral rule technique is ineffective. ${ }^{39}$ According to this theory, European private law's scope of application cannot be determined by a multilateral rule because it grants rights that are not equivalent to the rights of any other legal system. This is the case, for example, of the free movement of goods and services, on which European private law is based. A rule which determines that free movement of services will be governed by the law of the state where the service is provided (multilateral rule) would be impossible because the European Union is the entity that provides these kinds of rights. Therefore, it would be necessary to enact a provision determining that European Union law on free movement of goods and services will be applied, for example, when the good is sold or the service is provided in the territory of the European Union (unilateral rule).

In matters relating to contract, this would mean that these directives and regulations shall not be limited by the Rome I Regulation, even if they do not state their scope of application. In such cases, the scope of application should be presumed as implicit and should be found out by Member State courts or failing that, by the ECJ. This seems to be the position followed by the ECJ in Ingmar, which states that the Agency Directive applies to cases in which agents provide their services in the EU, regardless of whether the Rome I Regulation designates the law of a non-EU country as the law applicable to the contract. ${ }^{40}$

If this theory is transposed to the aforementioned example of the Moroccan package travel, the applicability rule contained in the EU Directive would be considered as a unilateral conflict rule and the Directive would be applied to the case over Moroccan law.

\section{(b) Multilateralism}

The second theory is multilateralism or the theory of "multilateral conflict rules" ('règles de rattachement'). According to it, when a directive or a regulation determines its scope of application it is not always creating a conflict rule, it can be stating its "internal" scope of application. This means that these applicability provisions would be included in directives and regulations only to determine to which intra-EU cases they will be applied. European secondary legislation would be, following B. MATHIEU, "auto-limited" rules. These applicability provisions would be, in most cases, the expression of the legislative competence of the European lawmaker to rule over a determined issue, a way to show that the act complies with the "principle of subsidiarity" and that the instrument would only apply to cases with a close connection to the European Union, not a rule that determines the international cases in which the EU rule is applicable.

39 F. Rigaux / M. Fallon, Droit international privé (Larcier, Bruxelles, 2005), at 4.2.

40 Judgment in Ingmar, C-38I/98, EU:C:2000:605. 
As a consequence, European directives and regulations would most of the times be limited by EU multilateral conflict rules, no matter if they contain a provision that indicates their territorial scope of application (M. FALLON). ${ }^{4 r}$

This theory is better understood if the EU is thought as a sovereign State. States legislate to govern internal relations, and to regulate those internal relations they sometimes establish a scope of application. But this does not necessarily mean that the lawmaker has intended to say that such legislation is also applicable to international cases. The lawmaker would only be determining the scope of application for internal cases and would leave the applicability in international cases to multilateral conflict rules. The same would happen with EU rules. The EU would pass directives and regulations thinking in intra-European situations, and their application to situations with foreign elements (connected to non-EU countries) would be left to multilateral conflict-of-laws provisions.

If this theory was applied to European contract law, it would mean that in most cases, the law designated by the Rome I Regulation would not be displaced by European directives and regulations. Beyond the cases determined by Rome I, EU law should only be applied in very exceptional situations.

Applying this theory to the Moroccan law example would mean that the EU Directive would not override Moroccan law automatically, notwithstanding its provision regarding its territorial scope of application. The seized Member State court shall consider whether the scope of application rule in this Directive is a simple "auto-limitation" rule for intraEuropean cases, or whether it is a real "conflict-of-laws" provision.

\section{(2) Critical Considerations}

In the field of European contract law, the multilateral theory seems to be preferable. Answering to the question which arose from Article 23 Rome I, most of the rules that determine the territorial scope of application of European contract law would not be "conflict rules relating to contractual obligations".

The reasons for this preference are not based in states' sovereignty issues but in the increase of the parties' legal certainty and predictability on the law applicable to their contract. Rome I Regulation provides a safer answer to the applicable law question than unilateral rules on directives and regulations do, given that some of them do not state their scope of application and others determine it in an ambiguous way.

In addition, another argument in favour of this second theory is that it would make no sense that the European legislature had created a conflict-of-laws instrument specific for

\footnotetext{
${ }_{4 \mathrm{r}} \quad$ M. Fallon, 'Les frontières...', supra n. 26. Also B. Mathieu, Directives européennes et conflits de lois (L.G.D.J., Paris, 2015) at 370 .
} 
contractual relations and then that it ignored it continuously and systematically when enacting substantive contractual norms. It would make more sense to think that the European legislature has stated the scope of application as a way of settling the connection of the legislative act with the European Union and therefore of affirming its legitimacy to pass it. There is another argument in contrario. Rome I Regulation expressly states the only case when European contract law shall be applied extraterritorially (Article 3,4 Rome I). As a consequence, in all other cases the Rome I Regulation shall remain as the main reference in determining the law applicable to a contract.

One last reason for selecting this perspective in contracts is that in this field, secondary legislation (directives and regulations) is not directly legislating on an institution that is unknown outside the EU (like free movement of goods and services would be) but providing a regime for certain kinds of contracts, and contracts are worldwide known. ${ }^{22} \mathrm{~A}$ multilateral conflict rule is therefore a plausible solution for them and it is not necessary to solve the conflict-of-laws problems with a unilateral rule, which should always be the last option. Unilateralism used in a large scale can lead to dangerous results, such as forum shopping and relativity of solutions.

At this point, what should be asked is how those exceptional cases in which EU contract law should be applied over the law determined by the Rome I Regulation are established. To answer this question, this study proposes to apply to the instruments of EU contract law the "test" settled down in Article 9 Rome I for national overriding mandatory provisions.

Article 9 Rome I allows the court to declare some rules of the law of the forum or of other countries as "overriding mandatory provisions" irrespective of the law otherwise applicable to the contract under the Regulation. The proposal of this paper is to apply this Article 9 not only to those rules with a national origin but also to those rules with a European origin, even if this possibility is not directly mentioned in Article 9, which only makes reference to the provisions the respect for which is regarded as crucial "by a country" (Article 9.I).

The key to this interpretation of this Article has been given by the ECJ in decisions like Unamar. ${ }^{43}$ According to this judgment, for a rule to be considered an overriding mandatory provision it is not enough that it states its intention of extraterritorial application. ${ }^{44}$ The seized Member State court shall also check that such a rule is essential for the safeguard of the interests of that country, as to require compliance therewith by all persons present on that territory and all legal relationships within that state. These issues shall be checked by Member State courts from the wording of the provisions, the rest of the instrument in which

42 P. Mayer, 'Les méthodes de la reconnaissance en droit international privé', in B. Ancel et al., Le droit international privé : esprit et méthodes. Mélanges en l'bonneur de Paul Lagarde (Dalloz, Paris, 2005) 547-575, at 567.

43 Judgment in Unamar, C-184/12, EU:C:2013:663.

44 Opinion in Unamar, C-I84/I2, EU:C:2013:30I, paragraphs. 34 and 39. 
they are included (the body, the preamble, transitional, additional or final provisions), their preparatory work, process of negotiation, etc. ${ }^{45}$ This double check can be easily transposed to the European Union and would also solve a traditional problem related to the scope of application of the directives, that is, the problem of which version of the directive shall be applied by the court seised. Overriding mandatory provisions can only be rules from the law of the forum (Article 9(I) Rome I) or laws from the country where the obligations arising out of the contract have to be or have been performed, in so far as those overriding mandatory rules render the performance of the contract unlawful (Article 9(3) Rome I).

The application of this proposal to our example of the package tour would be that the Directive could not be applied automatically. The Spanish court would have to assess from its wording, the rest of the Directive and the preliminary works whether Article I is a simple rule of territorial application or a truly European overriding mandatory provision, this is to say, if the respect of this Directive is essential for the political, social or economic organization of the European Union to such an extent that it must be applicable to any situation falling within their scope.

In addition, this second theory would also be compatible with the aforementioned Ingmar decision even if it did not mention Article 9 Rome I/Rome Convention. In this decision the ECJ justified the application of the Agency Directive stating that its aim was to protect the freedom of establishment and an undistorted competition in the internal market. These are objectives of the Treaty whose compliance is essential to the safeguard the interests of the EU. It could be stated that the ECJ assessed implicitly that the Directive was a European overriding mandatory provision.

To summarize, this multilateral theory seems to be more consistent with the idea of European private international law as a coherent legal system. Therefore, the general rule would be the application of multilateral conflict rules laid down in Rome I Regulation, and the European lawmaker would only use unilateral conflict rules in the cases where the interests of the Union were at stake.

\section{CONCLUSIONS}

Summarizing all the aforementioned, it can be affirmed that the problem of harmonization of European contract law with Rome I Regulation has not been solved yet either by the lawmaker or by the ECJ case law.

45 M. A. Cebrián, 'Agency and distribution contracts: national rules v. European private international law', in J.-S. Bergé, S. Franq and M. Gardeñes Santiago (dirs), Boundaries of European Private International Law (Bruylant Larcier, Brussels, 2015) $123-138$, at 132 . 
This paper has tried to solve this problem assuming that none of the existing general theories on the applicability of European private law is completely suitable for all of its branches. It has tried to look for the most suitable of those theories in the contractual sector.

The application of the unilateral theory would mean that when directives and regulations determine their territorial scope of application they are creating unilateral conflict rules, and therefore that these rules shall be applied over the law designated by Rome I Regulation.

However, the multilateral theory seems to fit more with a coherent European private international law system. This approach consists in assessing that European contract law should only be applied extraterritorially in very exceptional circumstances, that is, if in application of Article 9 of Rome I Regulation it is considered essential for the safeguard of the interests of the Union. This approach is in addition the most favorable to the parties' legal certainty. 